\title{
Edukasi Titik Kritis Halal pada Kelompok Usaha Jasa Pencucian Pakaian
}

\author{
${ }^{1}$ Dwi Endah Kusumawati, ${ }^{2}$ Dina Fatmawati* \\ ${ }^{1}$ Prodi Sarjana Farmasi, Universitas Islam Sultan Agung, Semarang, Indonesia \\ ${ }^{2}$ Pendidikan Sarjana Kedokteran, Universitas Islam Sultan Agung, Semarang, Indonesia \\ ${ }^{*}$ Corresponding Author: \\ JI. Raya Kaligawe KM.4 Fakultas Kedokteran, Universitas Islam Sultan Agung \\ E-mail: dienafatma@unissula.ac.id
}

Received:

15 Desember 2021
Revised:

19 Desember 2021
Accepted:

02 Januari 2022
Published:

10 Januari 2022

\begin{abstract}
Abstrak
Dalam kaitannya dengan aktivitas sehari-hari, jaminan produk halal tidak hanya terbatas pada usaha makanan maupun minuman, namun perlu merambah pada berbagai sector usaha salahsatunya adalah usaha pencucian pakaian. Usaha pencucian pakaian saat ini menjadi salah satu bisnis yang menjanjikan karena sangat membantu bagi seseorang yang aktivitas pekerjaannya sangat padat, namun banyak usaha pencucian pakaian yang kurang memperhatikan aspek kehalalan pada hasil cuciannya. Hal tersebut terjadi karena rendahnya pengetahuan awal terkait aspek jaminan halal pada produk cucian pakaian khususnya titik kritis halal pada jasa usaha pencucian pakaian. Kegiatan pengabdian masyarakat ini bertujuan untuk memberikan informasi terkait titik kritis halal pada kelompok usaha jasa pencucian pakaian berdasarkan kajian bioteknologi. Edukasi pada kelompok jasa pencucian pakaian dilakukan melalui sosialisasi dan penyebaran leaflet langsung ke pelaku usaha jasa pencucian pakaian. Penyampaian materi edukasi meliputi pengenalan sistem jaminan produk halal sesuai dengan Keputusan Kepala Badan Penyelenggaran Produk Jaminan Halal no. 57 tahun 2021 dan titik kritis halal jasa pencucian pakaian. Adanya kegiatan edukasi ini membuat peserta memiliki tambahan pengetahuan terkait proses pemisahan pakaian, penggunaan bahan utama, tambahan dan penolong pada produk pencucian pakaian. Berdasarkan hasil kegiatan disimpulkan bahwa terdapat peningkatan pengetahuan dan pemahaman peserta terkait dengan jaminan produk halal dan titik kritis kehalalan suatu produk khususnya pencucian pakaian.
\end{abstract}

Kata kunci: Laundry; titik kritis kehalalan; produk halal

\begin{abstract}
In relation to daily activities, the guarantee of halal products is not only limited to the food and beverage business, but needs to be extended to various business sectors, one of which is the laundry business. The laundry business is currently a promising business because it is very helpful for someone whose work activities are very busy, but many laundry businesses do not pay attention to the halal aspect of their laundry. This happened because of the low initial knowledge regarding aspects of halal assurance in laundry products, especially the halal critical point in clothing washing business services. This community service activity aims to provide information related to the halal critical point in the laundry service business group based on biotechnology studies. Education for the clothes washing service group is carried out through outreach and distribution of leaflets directly to business actors in laundry services. The delivery of educational materials includes the introduction of a halal product guarantee system in accordance with the Decree of the Head of the Halal Assurance Product Administration Agency no. 57, 2021 and the critical point of halal clothes washing services. The existence of this
\end{abstract}


educational activity made participants have additional knowledge related to the process of separating clothes, the use of main, auxiliary and auxiliary materials in clothes washing products. Based on the results of the activity, it was concluded that there was an increase in the knowledge and understanding of the participants regarding the guarantee of halal products and the critical point of the halalness of a product, especially washing clothes.

Keywords: Laundry; halal critical points; halal product

\section{PENDAHULUAN}

Islam mengajarkan tentang kebersihan dan memandang bahwa memelihara kebersihan merupakan masalah yang wajib diperhatikan dan diterapkan dalam kehidupan sehari-hari. Bersih dan suci merupakan dua hal yang berhubungan erat dengan Kesehatan (Yoni Atma, 2018). Bersih mencerminkan keadaan bebas dari kotoran dan tidak terkait langsung dengan tata cara peribadatan, namun menjadi keharusan bagi setiap muslim untuk menerapkannya dalam kehidupan sehari-hari. Suci dalam ajaran Islam adalah terhindar dari najis dan hadas, dan agar menjadi suci, seorang muslim harus mejalankan aturan tata cara taharah (bersuci). Setelah bertaharah, baru kita dapat menjalankan ibadah-ibadah khusus, terutama sholat. Salah satu cara membersihkan dan mensucikan pakaian adalah dengan memisahkan pakaian dari najis, mencucinya memakai deterjen yang ditambahkan pada air (HIlmawan, 2019).

Bisnis jasa pencucian dan setrika (laundry) tergolong kategori bisnis yang cukup mudah dalam pengoperasiannya dan dibutuhkan oleh banyak orang, terutama bagi seseorang dengan aktivitas pekerjaan yang padat. Peluang bisnis laundry sangat menjajikan mengingat sandang adalah kebutuhan pimer, dan mencuci pakaian merupakan salah satu usaha pemenuhan kebutuhan sandang. Berdasarkan wilayah operasionalnya, usaha laundry dapat dibedakan menjadi enam jenis, yaitu: laundry komersil, industrial, rumah sakit, kelembagaan, on-premises (instansi pribadi: hotel, rumah susun, pabrik), dan koin (perseorangan atau instansi kecil seperti apartemen) (Noviyanty, 2019).

Konsep halal mendapatkan atensi dan apresiasi yang tinggi khususnya bagi konsumen Indonesia yang mayoritas penduduknya beragama Islam. Undang-undang Nomor 33 Tahun 2014 Pasal 4 mensyaratkan kewajiban sertifikasi halal untuk semua produk yang beredar dan diperdagangkan di Indonesia. UU No.33 Tahun 2014 berisi tentang Jaminan Produk Halal di Indonesia yang bertujuan memberikan kenyamanan, keamanan, keselamatan dan kepastian bagi tersedianya produk halal untuk masyarakat Indonesia. Produk dalam arti luas meliputi barang atau jasa yang terkait dengan makanan, minuman, obat, kosmetik, produk kimiawi, produk biologi, produk rekayasa genetika, barang gunaan yang dipakai, digunakan atau dimanfaatkan oleh masyarakat2. Jaminan produk halal juga memberikan peningkatan nilai tambah bagi pelaku usaha untuk mengembangkan usahanya. Oleh sebab itu, kajian kehalalan suatu produk mutlak diperlukan baik dari segi ilmu pengetahuan dan teknologi maupun pemahaman dari segi syariat (Kementerian Agama, Peraturan pemerintah RI no. 39 Tahun 2019, 2021).

Mayoritas penduduk di negara Indonesia yang beragama muslim tentunya menjadi sasaran pengguna bisnis laundry, karena inti produk (core benefit) dari jasa pencucian syariah ini tidak hanya sekedar pakaian yang bersih dari noda dan bau, tetapi juga bisa bersih dari najis. Najis adalah sesuatu yang bersifat kotor yang dapat mencegah syarat sahnya sholat seorang muslim dan menghalangi seseorang untuk beribadah kepada Allah SWT. Najis dibagi menjadi tiga jenis, yaitu: (a) Najis 
Mukhaffafah adalah kategori najis ringan, seperti: air seni bayi laki-laki yang hanya minum ASI. Cara menyucikannya dengan memercikan air ke tempat yang terkena najis; (b) Najis Mutawasithah adalah kategori najis sedang, contohnya: segala sesuatu yang keluar dari qobul dan dubur manusia seperti air seni selain dari bayi laki-laki yang hanya minum ASI, kotoran manusia, darah haid dan nifas. Cara menyucikannya yaitu dihilangkan wujud najisnya terlebih dahulu, yaitu yang berupa warna, bau serta rasa, lalu dilanjutkan dengan proses menyiram dengan menggunakan air yang suci dan menyucikan; (c) Najis Mughalladzah adalah kategori najis berat. Cara menyucikannya dengan mencucinya tujuh kali dan salah satunya dengan tanah.

Pencucian Syariah merupakan pengembangan dari usaha pencucian dengan memasukkan konsep thaharah treatment, yaitu metode pencucian menggunakan air dua qullah atau setara dengan 270 liter sehingga proses pembersihan kain atau pakaian menjadi lebih optimal dan suci. Dalam rangka menjamin kehalalan pencucian Syariah ini, perlu ditetapkan penggunaan bahan chemical laundry dan bahan sanitasi yang halal dan ditentukan pula proses produk halal (PPH). PPH merupakan kegiatan untuk menjamin kehalalan seperti penyediaan bahan chemical laundry, pemilahan pakaian atau kain kotor dari customer yang akan dicuci, pencucian, pengeringan dan penyortiran, penyetrikaan, pelipatan dan penyimpanan produk (dalam hal ini pakaian atau kain). Pemberian label halal juga merupakan aktivitas yang tidak terpisahkan dalam menjamin kehalalan pencucian Syariah (Kementerian Agama, Undang-undang Republik Indonesia Nomor 33 Tahun 2014, 2014).

Berdasarkan Peraturan Pemerintah Nomor 39 Tahun 2021, pelaku usaha laundry yang ingin mengajukan permohonan Sertifikat Halal wajib memberikan informasi secara benar, jelas dan jujur; memiliki lokasi, tempat dan alat yang terpisah antara penanganan produk halal dan non-halal; dan memiliki penyelia halal yang bertanggung jawab terhadap PPH3. Pengendalian resiko tidak halal pada Pencucian Syariah dilakukan dengan menetapkan titik kritis kehalalan pada tahapan PPH yang berpotensi membuat pakaian/kain hasil pencucian menjadi tidak suci. Oleh sebab itu, tulisan ini menyajikan informasi dan identifikasi titik kritis pada pencucian Syariah (Kementerian Agama, Peraturan pemerintah RI no. 39 Tahun 2019, 2021).

Kegiatan pengabdian masyarakat ini bertujuan untuk memberikan informasi terkait titik kritis halal pada kelompok usaha jasa pencucian pakaian berdasarkan kajian bioteknologi.

\section{METODE}

Edukasi pada kelompok jasa pencucian pakaian dilakukan melalui sosialisasi dan penyebaran leaflet langsung ke pelaku usaha jasa pencucian pakaian. Sasaran edukasi pada 3 kelompok usaha pencucian pakaian di wilayah kecamatan Genuk, Semarang. Penyampaian edukasi dilakukan dengan cara ceramah dan diskusi. Materi edukasi meliputi pengenalan sistem jaminan produk halal sesuai dengan Keputusan Kepala Badan Penyelenggaran Produk Jaminan Halal no. 57 tahun 2021 dan titik kritis halal jasa pencucian pakaian. Kajian titik kritis halal pada produk pencucian pakaian dilakukan melalui 3 tahap antara lain:

1. Pemilihan produk bioteknologi sebagai bahan untuk pencucian,

2. Proses produk halal (PPH)

3. Identifikasi risiko titik kritis halal produk pencucian pakaian.

Kegiatan pengabdian ini ditujukan kepada kelompok usaha pencucian pakaian dengan target 3 jasa pencucian pakaian di wilayah kecamatan Genuk. 


\section{HASIL DAN PEMBAHASAN}

Pada kegiatan pengabdian kepada masyarakat ini dilakukan sosialisasi terkait pemilihan produk bioteknologi, dimana pemilihan produk bioteknologi sebagai bahan untuk pencucian meliputi bahan utama, bahan tambahan dan bahan penolong. Bahan utama berupa deterjen, bahan tambahan berupa pelembut pakaian dan pewangi pakaian, sedangkan bahan penolong berupa kemasan produk pencucian pakaian. Ketiga unsur bahan yang digunakan harus dipastikan kehalalannya, karena dalam setiap proses pembuatan bahan memiliki risiko ketidakhalalan.

Hasil kegiatan pengabdian masyarakat ini menunjukkan semua kelompok usaha pencucian pakaian menggunakan deterjen yang berlogo halal dan air yang digunakan merupakan air sumur tanpa pengolahan.

Tabel 1. Aspek pengetahuan

\begin{tabular}{|c|c|c|c|}
\hline \multirow{2}{*}{$\begin{array}{c}\text { Komponen penilaian aspek } \\
\text { pengetahuan }\end{array}$} & \multicolumn{3}{|c|}{ Skor (1-3) } \\
\hline & Jasa pencucian 1 & Jasa pencucian 2 & Jasa pencucian 3 \\
\hline $\begin{array}{l}\text { 1. Jenis-jenis najis dan cara } \\
\text { penyuciannya }\end{array}$ & 3 & 3 & 3 \\
\hline $\begin{array}{l}\text { 2. Perlunya pemisahan } \\
\text { pakaian berdasarkan } \\
\text { jenis najis }\end{array}$ & 3 & 3 & 3 \\
\hline $\begin{array}{l}\text { 3. Perlunya pemisahan } \\
\text { pakaian dari najis berat } \\
\text { (Mughalladzah) }\end{array}$ & 3 & 3 & 3 \\
\hline $\begin{array}{l}\text { 4. Perlunya penggunaan } \\
\text { deterjen berlogo halal }\end{array}$ & 3 & 2 & 1 \\
\hline $\begin{array}{l}\text { 5. Perlunya penggunaan } \\
\text { bahan pelembut dan } \\
\text { pewangi berlogo halal }\end{array}$ & 3 & 1 & 1 \\
\hline $\begin{array}{l}\text { 6. Perlunya penggunaan } \\
\text { bahan pengemas yang } \\
\text { berlogo halal }\end{array}$ & 2 & 1 & 1 \\
\hline
\end{tabular}

Berdasarkan hasil diketahui 2 dari jasa pencucian memiliki tingkat pengetahuan yang lebih baik dibandingkan 2 jasa pencucian lainnya. Jasa pencucian 1 merupakan jasa pencucian pakaian di RSI Islam Sultan Agung yang melakukan pemisahan pakaian berdasarkan najisnya. Semua pakaian yang masuk adalah pakaian yang tidak terkena najis berat karena hanya mencuci pakaian yang merupakan milik RSI Sultan Agung, dan tidak membuka jasa pencucian pakaian kotor pribadi milik pasien maupun keluarga pasien. Jasa pencucian 2 dan 3 merupakan jasa pencucian umum di komplek perumahan yang sulit untuk mengidentifikasi jenis najisnya, dan pemisahkan baru sebatas pada jenis dan bahan pakaian. Tingkat pengetahuan pelaku usaha jasa pencucian pakaian 2 dan 3 terkait penggunaan pelembut dan pewangi pakaian sebelum mendapatkan edukasi tergolong rendah. Hal tersebut dikarenakan pelaku usaha selama ini pelaku usaha tidak terlalu memperhatikan logo halal pada kedua produk tersebut. Untuk menekan modal mereka menggunakan produk kimia tanpa merk dan logo halal. Hal tersebut berisiko terhadap ketidakhalalan produk cucian yang dihasilkan.

Penggunaan plastik kemasan sebagai pembungkus produk cucian belum memperhatikan aspek kehalalannya. Hal tersebut diakibatkan para pelaku usaha belum memahami aspek-aspek yang harus diperhatikan dalam menjaga kehalalan produk pencucian pakaian salah satunya adalah penggunaan kemasan. Di sisi lain, 
pelaku usaha juga merasa kesulitan untuk mendapatkan informasi kemasan plastik yang berlabel halal dan disamping tidak banyak produk plastik kemasan yang beredar dipasaran memiliki logo halal. Adanya kegiatan edukasi ini membuat peserta memiliki tambahan pengetahuan terkait proses pemisahan pakaian, penggunaan bahan utama, tambahan dan penolong pada produk pencucian pakaian (Babak Babajanzadeh, 2019).

Deterjen sebagai bahan utama terdiri atas surfaktan, enzim, fatty acid, soap base, parfum, solubilizer dan pewarna (Babak Babajanzadeh, 2019). Berdasarkan komposisi tersebut ketidakjelasan sumber bahan dalam deterjen membuat status kehalalan deterjen tersebut diragukan. Sumber bahan yang tidak jelas tersebut itulah yang menjadi kritis pada kehalalan deterjen. Surfaktan merupakan bahan utama dalam deterjen yang berperan menurunkan tegangan permukaan sehingga dapat berperan melepaskan kotoran atau noda. Surfactan dapat berasal dari turunan lipid yang perlu dipastikan asalnya, apakah dari hewan yang dihalalkan dan disembelih dengan cara yang syar'i. Enzim sebagai bahan lain pada deterjen membantu meningkatan daya bersih dan dengan cara menguraikan pengotor yang dapat berupa pati, lemak atau protein. Enzim dapat berasal dari tanaman, mikroba, maupun hewan. Apabila enzim berasal dari hewan maka perlu diperhatikan apakah berasal dari hewan yang tidak diharamkan dan disembelih dengan cara syar'i, sedangkan enzim yang bersumber dari mikroba perlu diperhatikan media yang digunakan apakah berasal dari bahan haram atau babi (Jaswir et al., 2020). Bahan lain berupa fatty acid, soap base, parfum, solubilizer dan pewarna pada umumnya berasal dari lemak hewani yang perlu untuk dipastikan tingkat kehalalannya.

Kemasan pada produk cucian yang bersih juga perlu mendapatkan perhatian dikarenakan kemasan dari bahan plastik juga memiliki risiko tidak halal akibat proses pembuatan plastik tersebut. Titik kritis kehalalan pengemasan aktif terletak pada penggunaan bahan aktif yang bersumber dari produk microbial seperti enzim (Siregar et al., 2019). Mulijani (2021) menyebutkan bahwa plastik diperoleh dari polimerisasi, polikondensasi, poliadisi atau proses polimerisasi molekul-molekul yang berat molekulnya lebih rendah (monomer) atau perubahan kimia senyawa makromolekul alami. Kehalalan dan ke-thoyyiban dari plastik terletak pada bahan tambahan yang digunakan dalam pembentukan plastic berupa phthalate yang digunakan untuk memperkuat fleksibilitas, kekuatan dan ketangguhan plastik sekaligus mengurangi kekerasan dan kekakuan. phthalate dalam plastik tidak terikat kuat secara kimia dengan polimer inang, maka zat tersebut dapat menguap ke lingkungan dan gangguan pada saluran pernafasan serta bersifat karsinogenik sehingga tidak thoyyib. Kehalalan plastik, biasanya pada formulasi polipaduan polipropilena, dimana garam yang digunakan berupa kalsium stearate (E470) (Yunes Ramadan Al-Teinaz, 2020). Kalsium stearate dapat berasal dari lemak hewan yang berisiko menjadi tidak halal karena berasal dari lemak hewan yang diharamkan atau disembelih dengan cara yang tidak syar'i.

\section{Titik Kritis Kehalalan Pada Pencucian: Bahan}

Titik kritis utama penentu konsep halal dalam pencucian Syariah meliputi bahan dan proses produk halal (PPH). Bahan merupakan unsur yang digunakan dalam menghasilkan produk, kategori bahan mencakup : (a) bahan baku, yaitu bahan utama untuk menghasilkan produk, (b) bahan tambahan, yaitu bahan tambahan untuk meningkatkan sifat produk, (c) bahan penolong, yaitu bahan yang digunakan untuk membantu produksi tetapi tidak menjadi bagian dari komposisi produk (ingredient), (d) kemasan, pelumas, grease, sanitizer yang kontak langsung dengan bahan produk, 
(e) bahan penolong pencucian yang kontak langsung dengan fasilitas produksi untuk memproduksi produk, dan (f) media untuk validasi hasil pencucian fasilitas yang kontak langsung dengan bahan atau produk.

Seluruh bahan yang digunakan dalam proses pembersihan pakaian/kain, baik berupa air, bahan chemical laundry yang digunakan untuk pencucian produk maupun bahan pembersih untuk kegiatan pembersihan/sanitasi mesin wajib terjamin kehalalannya dan dibuktikan dengan sertifikat halal. Seluruh bahan disusun dalam matriks bahan dan didaftarkan serta mendapat persetujuan oleh BPJPH. Spesifikasi setiap bahan hendaklah disusun rapi dalam satu dokumen dan dilengkapi dengan Informasi Data Keamanan Bahan (MSDS) guna memudahkan dalam penanganan dan penyimpanan bahan oleh petugas laundry.

Prosedur serta alur yang jelas perlu dibuat guna menjamin ketertelusuran bahan terutama dari segi kehalalannya, mulai dari pengadaan bahan, penerimaan, penyimpanan, penggunaan dan penanganan apabila terdapat bahan yang rusak atau tidak sesuai. Dokumen pendukung lain berupa surat pernyataan fasilitas produksi bebas dari babi (statement of pork free facility) dari produsen bahan chemical yang digunakan wajib tersedia serta terdokumentasi dengan baik.

Titik Kritis Kehalalan Pencucian: PPH

Tahapan pada proses produk halal pencucian pakaian meliputi:

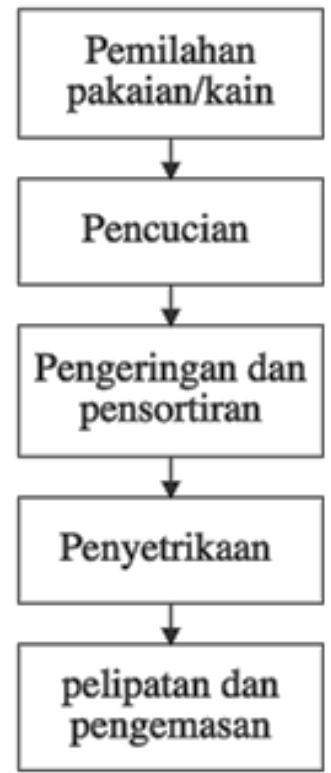

Gambar 1. Tahapan proses pencucian pakaian

Masing-masing tahapan pencucian harus dipastikan bebas dari bahan haram mulai dari tempat, lokasi sampai dengan tiap tahapan prosesnya. Mengacu pada UU No.33 Tahun 2014 Pasal 21 yaitu lokasi, tempat dan alat PPH wajib dijaga kebersihannya, bebas dari najis dan bahan yang tidak halal. Manajemen pencucian syariah adalah upaya pengelolaan dan pengawasan terhadap tahapan-tahapan pencucian untuk menjamin kebersihan dan kesuciannya dari najis. Adapun titik kritis kehalalan pada PPH pencucian Syariah yaitu: 
Tabel 2. Identifikasi Titik Kritis Kehalalan pada Pencucian Syariah

\begin{tabular}{|c|c|c|}
\hline No & Tahapan & Titik Kritis Kehalalan \\
\hline 1 & $\begin{array}{l}\text { Pemilahan pakaian atau } \\
\text { kain dari customer }\end{array}$ & $\begin{array}{l}\text { - Penentuan jenis najis pada pakaian/kain kotor dari } \\
\text { customer. Tahapan ini mutlak diperlukan karena } \\
\text { hanya customer yang tau persis jenis najis (terutama } \\
\text { najis mughallazah) yang terdapat pada pakaian/kain } \\
\text { kotor yang ia bawa. Metode kuisioner atau tanya } \\
\text { jawab dapat diaplikasikan pada tahap ini. } \\
\text { Wadah penampung pakaian/kain kotor dibuat } \\
\text { terpisah. Khusus pakaian/kain yang mengandung } \\
\text { najis berat dibedakan dengan penanganan } \\
\text { pakaian/kain yang mengandung najis ringan/sedang. }\end{array}$ \\
\hline 2 & Pencucian & $\begin{array}{l}\text { - Mesin cuci yang digunakan terpisah antara mesin } \\
\text { cuci untuk penanganan najis berat dengan mesin } \\
\text { cuci untuk penanganan najis sedang. } \\
\text { - Mesin cuci yang digunakan harus berfungsi dengan } \\
\text { baik } \\
\text { - Ketersediaan air bersih mencukupi (minimal } 2 \text { qullah } \\
\text { pada setiap proses pencucian) } \\
\text { Menggunakan bahan pembersih dan pewangi } \\
\text { (chemical laundry) yang halal dan terdaftar di matriks } \\
\text { bahan. } \\
\text { Khusus penanganan najis berat maka disediakan } \\
\text { tanah atau sabun tanah untuk penyuciannya. }\end{array}$ \\
\hline 3 & $\begin{array}{l}\text { Pengeringan dan } \\
\text { penyortiran }\end{array}$ & $\begin{array}{l}\text { - Pakaian/kain dipastikan sudah tercuci bersih (tidak } \\
\text { - Ada noda dan bau) } \\
\text { Apabila masih terdapat noda, dilakukan pencucian } \\
\text { ulang }\end{array}$ \\
\hline 4 & Penyetrikaan & - $\quad$ Tidak terdapat noda dan bau pada pakaian/kain \\
\hline 5 & $\begin{array}{l}\text { Pelipatan dan } \\
\text { penyimpanan }\end{array}$ & $\begin{array}{l}\text { - Tidak terdapat noda dan bau pada pakaian/kain } \\
\text { - Pemberian Halal pass dapat dilakukan pada tahapan } \\
\text { ini. Label hendaklah jelas dan tidak mudah lepas } \\
\text { - Pakaian/kain yang sudah bersih dan suci dikemas } \\
\text { rapat }\end{array}$ \\
\hline
\end{tabular}

\section{KESIMPULAN}

Berdasarkan hasil kegiatan disimpulkan bahwa terdapat peningkatan pengetahuan dan pemahaman peserta terkait dengan jaminan produk halal dan titik kritis kehalalan suatu produk khususnya pencucian pakaian. Titik kritis utama penentu konsep halal dalam pencucian Syariah meliputi bahan dan proses produk halal (PPH). Penentuan titik kritis pada setiap tahapan pencucian berbasis syariah diharapkan dapat menjadi suatu acuan bagi pelaku usaha laundry yang ingin mendaftarkan usahanya untuk proses sertifikasi halal ke Badan Penyelenggara Jaminan Produk Halal (BPJPH).

\section{UCAPAN TERIMA KASIH}

Kegiatan ini terselenggara atas pendanaan dari Fakultas Kedokteran UNISSULA melalui pendanaan kelompok studi, kelompok usaha laundry di wilayah Kecamatan Genuk, dan RSI Sultan Agung, Semarang yang telah memfasilitasi kegiatan ini. 


\section{DAFTAR PUSTAKA}

Babak Babajanzadeh, S. S. (2019). Detergents and surfactants: a brief review. Med Crave.

HIlmawan, M. (2019, Maret 25). https://www.halalmui.org/. Diambil kembali dari Halal MUI: https://www.halalmui.org/mui14/main/detail/deterjen-haruskah-halal

Jaswir I, R. E. (2020). Daftar Referensi Bahan-Bahan Yang Memiliki Titik Kritis Halal Dan Substitusi Bahan Non-Halal. Jakarta: Komite Nasional Ekonomi dan Keuangan Syariah.

Kementerian Agama, R. (2014). Undang-undang Republik Indonesia Nomor 33 Tahun 2014. Jaminan Produk Halal. Jakarta, Indonesia.

Kementerian Agama, R. (2021). Peraturan pemerintah RI no. 39 Tahun 2019. Penyelenggaraan Bidang Jaminan Produk Halal. Jakarta, Indonesia: 2021.

Mulijani, S. (2021, September 23). Kemasan Plastik dan Aspek Kehalalannya. Diambil kembali dari https://www.halalmui.org/: https://www.halalmui.org/mui14/main/detail/kemasanplastik-dan-aspek-kehalalannya

Noviyanty, P. (2019). Analisis Pendapatan Jasa Laundry di Kecamatan Syiah Kuala. Banda Aceh: Fakultas Ekonomi dan Bisnis Islam.

Siregar M, M. R. (2019). Tinjauan Keamanan Dan Kehalalan Pengemasan Desain Kreatif. Jurnal Pangan Halal.

Yoni Atma, M. T. (2018). Identifikasi titik kritis Kehalalan produk pangan: studi produk bioteknologi. Jurnal Teknologi UMJ.

Yunes Ramadan Al-Teinaz, S. S.-R. (2020). The Halal Food Handbook. John Wiley \& Sons. 